
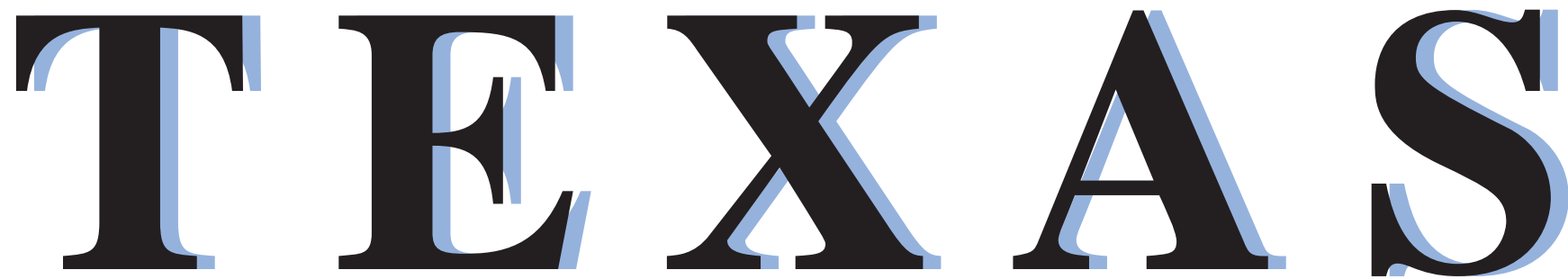

\section{Empresarias Decididas}

\section{Women \\ Entrepreneurs in the Americas}

\section{by Elsie Echeverri- Carroll, Ph.D.}

Director

Economic Development

Program

Bureau of Business Research University of Texas at Austin

\section{and Daniela \\ Brandazza}

Bureau of Business Research University of Texas at Austin

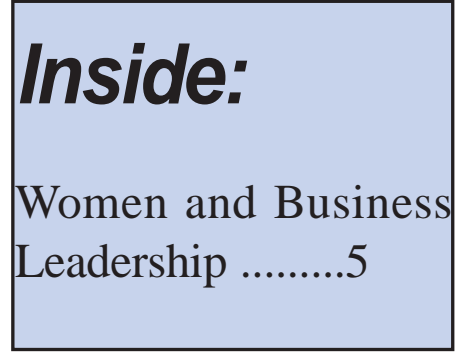

$\mathrm{D}$ efining "entrepreneurs" as workers who declare their professional status to be that of employers or own-account workers (self-employed without full-time, paid employees), the Organization for Economic Co-operation and Development (OECD) reports that the share of women entrepreneurs as a percentage of all entrepreneurs increased from 29.7 percent in 1980 to 35.2 percent in 1990 in the United States and from 30.8 percent to 37.1 percent in Canada during the same period. The U.S. Economic Census defines "women-owned businesses" as privately held firms in which women own 51 percent or more of the enterprise. According to the most recent economic census data (1997), the number of women-owned firms increased 16 percent from 1992 to 1997 (see figure). This is almost triple the rate of growth $(6$ percent) for all U.S. firms during this period. Estimates from the Center for Women's Business Research show the increase in women-owned businesses holding at 14 percent between 1997 and 2002.

Furthermore, this growth is consistent across all ethnic groups in the United States (see table). This trend, however, is not necessarily well noted. As Barbara Robles has pointed out, "we are bereft of comprehensive knowledge and information about the U.S. minority enterprise population."

These statistics indicate noteworthy increases in the numbers of U.S. and Canadian women entrepreneurs. What factors have contributed to this growth? And do these factors also translate into success for their colleagues in Latin America? How does the experience of women entrepreneurs in Latin America compare to that of their counterparts to the north? What are the relative advantages and disadvantages of entrepreneurship in the emerging economies of Latin America?

Women-owned Firms Compared to All U.S. Firms, 1992 and 1997

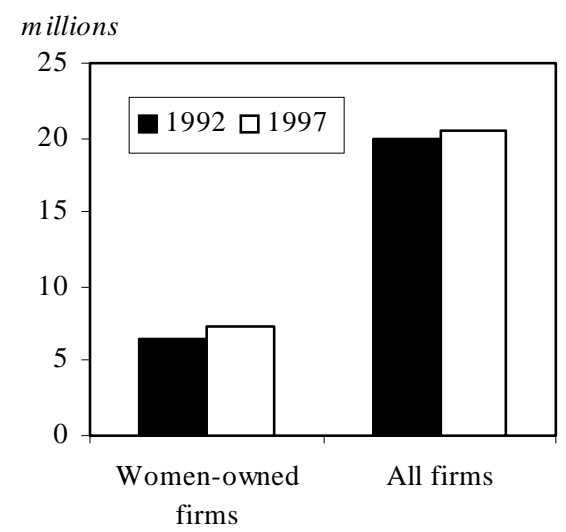

Source: 1997 Economic Census, U.S. Bureau of the Census.

\section{The Elements of Entrepreneurship}

As the OECD points out, "appropriate education and adult training (experience) are key to fostering widespread entrepreneurial spirit." The Center for Women's Business Research reports that approximately 75 percent of U.S. women entrepreneurs had earned a college degree. While higher 


\section{Estimated Number of Minority Women-Owned Businesses in the United States, 2002}

\begin{tabular}{|lrr|}
\hline \multicolumn{1}{|c}{ Minority } & $\begin{array}{c}\text { Number } \\
\text { of firms }\end{array}$ & $\begin{array}{c}\text { Percentage } \\
\text { increase, } \\
\mathbf{1 9 9 7 - 2 0 0 2}\end{array}$ \\
\hline Hispanic & 470,344 & 39.3 \\
African-American & 365,110 & 16.7 \\
$\begin{array}{l}\text { Asian/Pacific } \\
\text { Islander }\end{array}$ & 358,503 & 44.6 \\
$\begin{array}{l}\text { Native American/ } \\
\text { Alaska native }\end{array}$ & 77,483 & 44.6 \\
\hline
\end{tabular}

Women often tend to be pushed into entrepreneurship by negative aspects of the corporate working environment, such as the limitations of the "glass ceiling," discrimination, and inflexible schedules.

Source: Center for Women's Business Research (based on U.S. Bureau of Census data), http://www.nfwbo.org

education certainly fosters entrepreneurial activity, college education in the hard sciences seems to be a prerequisite for developing high-tech firms, which rely on skilled, highly innovative labor. High-tech start-up statistics reveal the scarcity of women entrepreneurs in this area. The March 15, 2000, issue of Internet World Magazine notes that of the 129 new chief executive officers named to U.S. Internet companies in 2000 , only eight were women, and of 49 new chief technology officer positions filled in that same year, none were women. Such dismal numbers have caused U.S. policymakers to cite as an urgent national priority the increase in numbers of female graduates in technical fields, such as engineering and computer science.

To improve their chances to succeed as entrepreneurs, women need not only the knowledge and skills acquired through a college degree, but also the experience gained in the labor market. Many selfemployed women obtain this experience in corporations, where they learn the various skills necessary to run their own businesses effectively. In particular, they develop-usually over the course of a ten- to twelve-year corporate tenuremanagerial, financial, marketing, technical, and planning skills before leaving to form their own companies. At the same time, women often tend to be pushed into entrepreneurship by negative aspects of the corporate working environment, such as the limitations of the "glass ceiling," discrimination, and inflexible schedules.

In addition to these gains in human capital investments (i.e., increasing levels of education and work experience), what other variables lead to increased participation by women in entrepreneurial activities? Research shows that greater relative earnings potential in self-employment and a greater demand for time flexibility prompt women to choose entrepreneurship. Self-determined work schedules allow for better balance between professional and family responsibilities. Data for the United States reveal that a self-employed woman is more likely to be married and that her spouse will also be self-employed and have health insurance that covers the family. Never-married women in the United States accounted for only 7.3 percent of all selfemployed females through the 1975-1990 period; married women (with spouse present), 75 percent during the same period.

\section{Women Entrepreneurs in the Emerging Economies of Latin America}

Statistics on female entrepreneurs in Latin American countries are scant. The most reliable information can be found in a series of surveys conducted by the U.S. National Association of Women Business Owners and IBM for Argentina and Mexico and by SEBRAE, a Brazilian organization dedicated to the promotion of entrepreneurship in Brazil, for Sao Paulo. Although these surveys represent the first attempt to describe the economic and demographic characteristics of women business owners in these countries, they are not a representative sample. As OECD points out, "women entrepreneurship suffers from a lack of statistical information and research, thus limiting analysis and leading to the use of a priori estimates and hypotheses."

The exception here is Mexico, one of the few Latin American countries supplying data on women-owned businesses. Data from the OECD reveal that women-owned enterprises accounted for 16 percent of all enterprises in Mexico in 1990. This is approximately half the percentages reported for the United States (36 percent) in 1996 and Canada (30 percent) in 1994.

The research that does exist indicates that women in Latin America lag behind 
A larger number of women in the workforce has not translated into an increase in the numbers of women entrepreneurs in Latin America. their U.S. and Canadian counterparts in several areas. For example, the gap in the share of female college matriculations remains significant between the United States and Canada and the largest Latin American countries. Data from UNESCO show that, on average, half of all U.S. and Canadian college graduates in the 1990s were females, while Chile and Mexico listed an average of approximately 40 percent (data for Argentina and Brazil are not available). A similar gap appears in the numbers for women's participation in the labor market. The World Bank reports that in 1998, women accounted, on average, for 45 percent of the labor force (economic active population) in the United States and Canada, but for only 33 percent, on average, in Argentina, Brazil, Chile, and Mexico.

Given the relatively low incorporation of human capital (in both education and labor force experience), one would expect to find a relatively smaller number of Latin American women in entrepreneurial activities. Do Latin American women in fact experience unique disadvantages that negatively affect the rate of entrepreneurship? We suggest that they experience both advantages and disadvantages in comparison to their counterparts in the United States and Canada.

\section{Relative Advantages}

Employing outside services for domestic help and childcare lists as the top strategy adopted by U.S. and Canadian professional women to balance career and home duties. Indeed, approximately 85 percent of professional women in both countries reported employing outside services. Certainly the abundance of cheap labor in Latin America makes this a viable strategy for professional women in that region as well. In addition, the close ties among family members and the proximity of extended family ensure help, especially with childcare, for many Latin American women working outside the home. The very high urban concentration that characterizes Latin American countries can also prove an advantage for Latinas, who tend to have little geographical mobility in their job searches and therefore usually remain in the same area as their extended families.

\section{Relative Disadvantages}

As in most societies, Latin American sociopolitical structures are marked by the separation of male and female roles. The public sphere is considered the domain of men, while women manage the organization of the home and the care of children. However, the volatility of the Latin American economies in the 1980s and 1990s may have shaken such fixed notions regarding "women's work," as more women have been pushed into the labor market to compensate for the loss of purchasing power within the household.

However, a larger number of women in the workforce has not translated into an increase in the numbers of women entrepreneurs in Latin America. Why? The main reason may be the low level of entrepreneurial activity in general in Latin American countries. In a recent survey, researchers at Babson College estimated the rate of new business creation in ten industrialized countries, using a representative sample of 1,000 adults. The results suggested significant differences among countries in new firm start-ups. When disaggregated by gender, the data show relatively similar start-up participation rates for men and women in the United States and Canada, countries with high levels of entrepreneurial activity. On the other hand, the start-up participation rates for women and men are highly disparate in countries showing low levels of entrepreneurial activity.

Finally, as noted, the lack of statistical information and research about women entrepreneurs in Latin America hinders their effectiveness with policymakers in the implementation of government procurement laws or policies that promote women business owners.

\section{Conclusions}

Relatively speaking, Latin American women face more obstacles in the pursuit of entrepreneurship than do women in the United States and Canada, and they enjoy fewer advantages than their counterparts to the north. However, we know little about the importance for Latin America women of factors that have proven important to the success of women entrepreneurs in the United States. For instance, is it also the case that the husbands of Latin American entrepreneurs tend to be self-employed? Do their husbands play a significant role as mentors or as support in providing the health insurance that many female small 
The lack of statistical information and research about women entrepreneurs in Latin America hinders their effectiveness with policymakers in the implementation of government procurement laws or policies that promote women business owners. business owners cannot afford? Is it the case that Latin American professional women can more easily balance the demands of home and workplace because of the large supply of cheap labor in that region? We propose here that identifying and measuring the relative importance of these factors is the first step to promoting women entrepreneurship in the region.

\section{References}

Catalyst, Closing the Gap: Women's Advancement in Corporate and Professional Canada, New York, 1998.

Center for Women's Business Research, "Fact of the Week, June 16, 1997," and "Number of

Minority Women-Owned Businesses Expected to
Reach 1.2. Million in 2002," http://www.nfwbo.org, 1997 and 2001

Echeverri-Carroll E.L., D. Brandazza, and C. Giusti, "El Libre Comercio y las Mujeres en las Esferas de Negocios en America," InfoPyme 4:1-4, 2001.

Organization for Economic Co-operation and Development, Women Entrepreneurs in SMEs: Realizing the Benefits of Globalization and the Knowledge-based Economy, Paris, 2000.

Reynolds, P.D., M. Hay, M.S. Camp, Global Entrepreneurship Monitor-1999 Executive Report, Kauffman Center for Entreprenurial Leadership, London Business School, 1999.

Robles, B., "Latina Entrepreneurial Activity in the 1990s: Lessons for the 21st Century," Reflexiones, 2002.

We appreciate the support of the Hewlett Foundation through the Center for Inter-American Policy Studies at the LBJ School of Public Affairs, University of Texas at Austin.

\section{Where Does Texas Rank?}

Number of Women-Owned Firms, Top Five States, 1997

\begin{tabular}{lrr}
\hline State & Number of firms & $\begin{array}{r}\text { Receipts } \\
\text { (millions of } \$ \text { ) }\end{array}$ \\
\hline California & 700,513 & 121,191 \\
New York & 394,014 & 59,497 \\
Texas & $\mathbf{3 8 1 , 4 5 3}$ & $\mathbf{6 5 , 0 6 5}$ \\
Florida & 337,811 & 48,261 \\
Illinois & 239,725 & 44,273 \\
\hline United States & $\mathbf{5 , 4 1 7 , 0 3 4}$ & $\mathbf{8 1 8 , 6 6 9}$ \\
\hline
\end{tabular}

Number of Women-Owned Firms, Top Ten U.S. Cities, 1997

\begin{tabular}{lrr}
\hline City & Number of firms & $\begin{array}{r}\text { Receipts } \\
\text { millions of \$) }\end{array}$ \\
\hline New York NY & 167,898 & 29,227 \\
Los Angeles CA & 89,619 & 10,908 \\
Chicago IL & 47,720 & 8,924 \\
Houston TX & $\mathbf{4 1 , 0 9 4}$ & $\mathbf{1 1 , 1 4 5}$ \\
San Diego CA & 26,895 & 3,645 \\
Dallas TX & $\mathbf{2 6 , 1 3 6}$ & $\mathbf{6 , 0 2 5}$ \\
San Francisco CA & 25,426 & 4,055 \\
Phoenix AZ & 22,535 & 3,862 \\
San Antonio TX & $\mathbf{1 8 , 4 9 6}$ & $\mathbf{4 , 0 0 1}$ \\
Seattle WA & 18,116 & 2,955 \\
\hline
\end{tabular}

Source: 1997 Economic Census, U.S. Bureau of the Census. 
$\mathrm{U}$ ndoubtedly, women today have more business opportunities than ever.

Whether as managers in large corporations or entrepreneurs in their own companies, female business leaders are succeeding at an unprecedented pace. For instance, as the preceding article demonstrated, the percentage of women-owned businesses has increased in the last decade, as more and more women entrepreneurs find access to capital and markets for their goods and ideas.

That said, however, there remain troubling issues that disproportionately affect more women than men. Why are there so few women running high-tech companies? And why do fewer women attend graduate business programs today than did ten years ago? The McCombs School of Business at The University of Texas at Austin, in cooperation with the Bureau of Business Research, sponsored the Women in Business Leadership Conference for currently enrolled and prospective MBA students in February 2002, to explore these and other issues facing the women business leaders of tomorrow.

\section{Wanted: Role Models, Mentors, and More Options}

As a percentage of all MBA students, fewer women are pursuing graduate business degrees today in the United States than did a decade ago, even as women earn undergraduate business degrees and professional degrees in law and medicine at rates approximating those of men. What accounts for the gap between these percentages and the much lower (approximately 30 percent nationwide) matriculation rate for female MBA students? According to studies and the participants at the McCombs conference, the answer lies in the relative lack of female role models. That is, if women were exposed more often to successful female business leaders, and were presented with more opportunities to network and interact with them, business leadership might seem a more viable career path.

In addition, mentoring is considered an important factor in encouraging younger women to advance in corporate or entrepreneurial pursuits. Whether formal or informal, a mentoring relationship helps a "mentoree" develop visions of herself and her capabilities that were not formerly allowed. This applies, of course, to men as well as women, and the experts at the conference noted that a majority of successful CEOs of both genders have mentors to whom they can turn for subject matter expertise and advice, objective criticism, and encouragement.

It is especially important for role models and mentors to encourage young women to enter graduate school and pursue business careers. Studies have linked postgraduate education with advancement in business, showing that about two-thirds of women managers have postgraduate degrees. In addition, fewer women than men pursue college or graduate degrees in science, math, and engineering, fields that are vitally important for starting, or advancing in, a high-tech company. While the causes for this discrepancy are society-wide, experts conclude that much more can be done to encourage young girls to study math and science early in their educations.

Work-life balance is not a new problem for women, but the ever-quickening pace of business today, whether in small companies or large corporations, requires even greater organization and sacrifice for female business leaders. Job-sharing, maternity (and paternity) leave, and networks of other women in the workplace and in professional organizations can help women navigate the often conflicting demands of motherhood and career.

MBA programs could attract more women, too, by emphasizing career paths outside the corporate environment. More women than men say that they are not as motivated by money in choosing a career. Perhaps then non-profit organizations and government might prove appealing alternatives to women entering the job market.

These and other key themes and findings from the 2002 conference will be expanded upon at next year's meeting. The February 2003 conference will feature an international focus, with panels on, among other topics, women entrepreneurs in Canada, the United States, and Latin America. At present, streaming video from the 2002 panel sessions is available on the Web at http://texasmba.bus.utexas.edu/ MBAWomen/conference/

The author would like to acknowledge Suzie Kornblum, Women in Business Leadership Conference chair, for her contributions.

\section{Women and Business Leadership Hurdles, Progress, and Opportunities}

\section{by Bruce Kellison}

Associate Director

Bureau of Business Research University of Texas at Austin 
Texas Business Review is published six times a year (February, April, June, August, October, and December) by the Bureau of Business Research, University of Texas at Austin. Subscriptions are available free upon request. Views expressed in this newsletter are those of the authors and do not necessarily reflect the position of the Bureau of Business Research.

Research and service activities of the Bureau of Business Research focus on the ways Texas industries can become nationally and globally competitive. The Bureau is policy oriented and dedicated to public service. The Bureau is located on the sixth floor of the College of Business Administration building.

\section{Editor: Bruce Kellison Bruce.Kellison@bus.utexas.edu \\ Managing \\ Editor: \\ Sally Furgeson sallyf@mail.utexas.edu \\ Sales \\ Office: (888) 212-4386 \\ (512) 471-1063 fax Rita.Wright@bus.utexas.edu \\ General: bbr@uts.cc.utexas.edu $W W W$ :}

http://www.utexas.edu/depts/bbr/tbr/

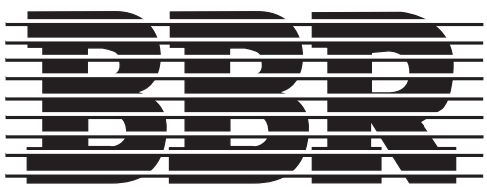

BUREAU OF BUSINESS RESEARCH

University of Texas at Austin Bureau of Business Research 21st and Speedway CBA 6.444

Austin, Texas 78712

\section{Change Service Requested}

NONPROFIT ORG

U.S. Postage

P A I D

Austin, Texas

Permit No. 391

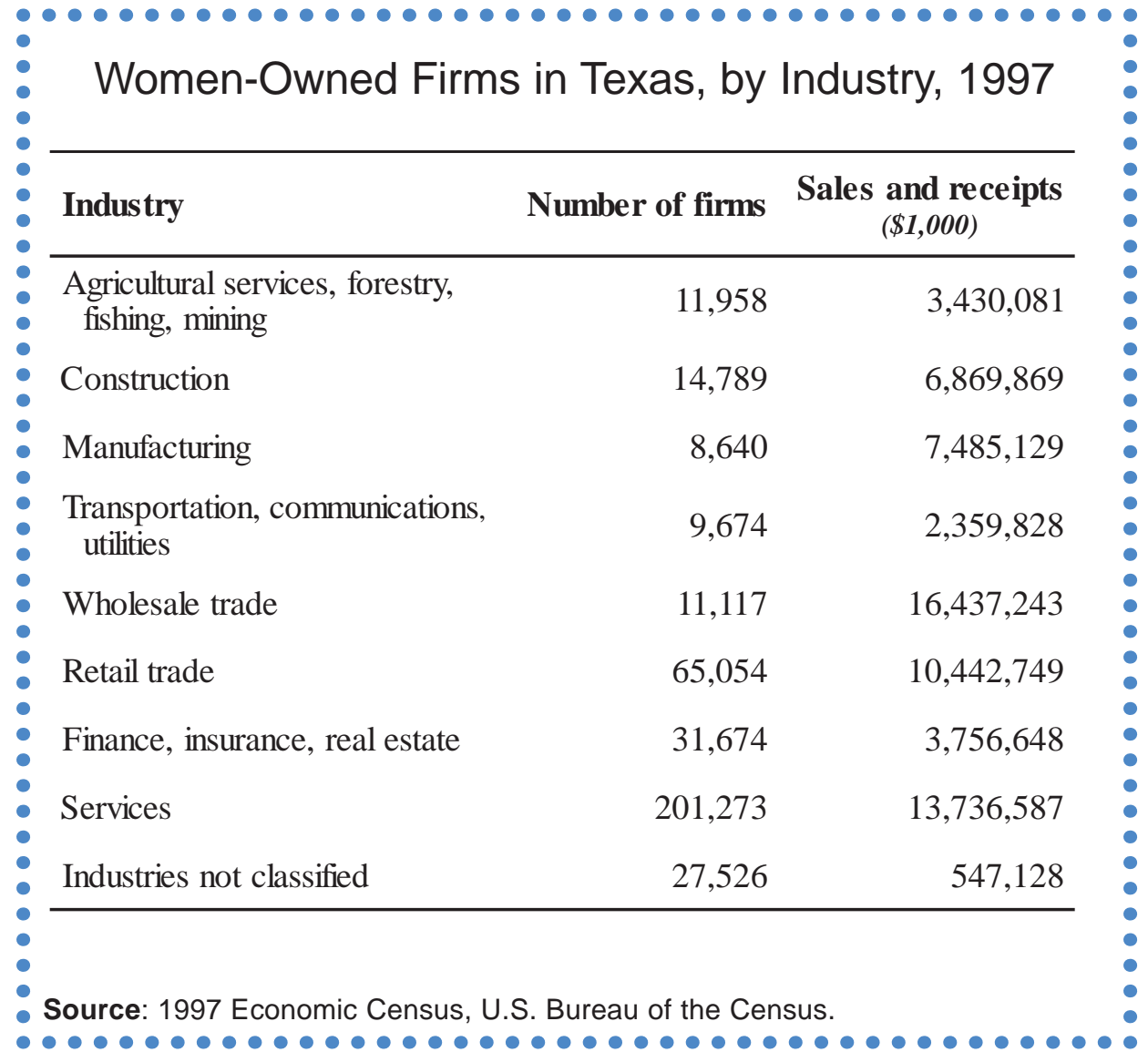

\section{Announcement}

The year 2002 marks the 75th anniversary of the first publication of Texas Business Review. Established in 1927, TBR has evolved from a simple, mimeographed newsletter containing statistics on the state economy to a widely circulated bimonthly offering analyses on topics from economic diversification to education, from income inequalities in high-tech industries to Internet marketing, from the restructuring of electricity markets to the rethinking of border issues in a post-September 11 atmosphere.

The editorial staff would like to thank the hundreds of contributors and the thousands of readers who have given this publication such a long and productive life. 